\title{
Reality check for corporate leaders: when managers don't respect their bosses
}

\author{
Marius Pretorius and Ingrid le Roux
}

Marius Pretorius, an Associate Professor in strategy and turnaround, Department of Business Management, University of Pretoria, South Africa, consults to corporations on strategy issues (marius.pretorius@up.ac.za). Ingrid le Roux, a Senior Lecturer in Entrepreneurship and Small Business, Department of Business Management, University of Pretoria, consults on innovation and growth (ingrid.leroux@up.ac.za).

We are accustomed to hearing the phrase "leadership failure" when the business press righteously passes judgement on a troubled turnaround or sneers at the embarrassing details of an ethical stumble. [1] But what is the appropriate assessment when a company's upper and midlevel managers fail to achieve the respect of the managers they lead? Shouldn't that also be considered a failure of the company's leadership? To the extent that middle managers are responsible for communicating and managing to achieve a company's vision and goals they are a crucial part of the leadership team. But it's top management's responsibility to closely monitor whether middle managers are effectively managing and supervising their direct reports.

Based on the abundance of advice available, there are sufficient prescriptions of what leaders should do to make certain their organization's middle managers are effective supervisors. Nonetheless, middle managers who are held in high esteem by their own managerial team seem to be in the minority. Why is that so? This article proposes a reality check for leaders about their middle managers.

It's rare to study management from a day-to-day failure perspective, but it produces insightful information about the relatively poor performance at the supervisory front. We asked junior and middle managers in the South African banking industry to tell us about the mistakes they think their own managers make. Our first questions were:

- Why do managers fail as leaders?

- What are the consequences of these failures?

Respondents were asked to think about their own managers in particular.

As follow up questions, we asked:

- Can we learn from managerial failure on this level? And if so, what?

We wanted to know the causes of such ordinary management failure as leaders and also the consequences that occur. Our respondents were from different companies and businesses in the banking and financial services industry.

After they considered specific elements related to their own managers, respondents reported their individual views in writing. Then, focus-group discussions identified the five main failure causes and consequences for each group. These generally confirmed the individual responses but contained a lot of jargon, which we boiled down to a few categories.

Initially, no definition of leadership failure was given the respondents. Only after responses were collected did we define leadership failure for respondents as depending on their willingness to voluntarily follow the manager or not. Respondents' unwillingness to follow the manager unless 
forced or coerced by virtue of the position or organizational authority structure then suggests failure to lead direct reports.

The responses and the percentage contribution of each category shown in Exhibit 1 gave us insights into the actions that cause leadership failure among mid-level managers. It shows the distribution of issues associated with interpersonal conflicts. The respondents considered external factors a minor problem compared with human issues. The remedial actions identified involve instituting sound basic managerial practices rather than experimenting with "rocket science" concepts.

Exhibit 1. Reasons why managers fail as leaders.

\begin{tabular}{|l|c|c|}
\hline \multicolumn{1}{|c|}{ Actions } & Rank \\
\hline $\begin{array}{l}\text { Posture (inflexibility, autocratic, example, control, not open to } \\
\text { opinions / alternatives = 16.37) Ego (Arrogance, self centred, } \\
\text { position dependent, blame others =7.39\%) }\end{array}$ & 24.26 & 1 \\
\hline $\begin{array}{l}\text { No people skills (integrity, conflict, no trust, relationships, no } \\
\text { sensitivity, no insight into people) }\end{array}$ & 18.13 & 2 \\
\hline $\begin{array}{l}\text { "Unfocused thinking" (negativity, task focus only, non strategic } \\
\text { = thus confusing) }\end{array}$ & 13.91 & 3 \\
\hline $\begin{array}{l}\text { Communication failure (not share info, not listen, no feedback, } \\
\text { unable to delegation) }\end{array}$ & 13.03 & 4 \\
\hline $\begin{array}{l}\text { No encouragement, support and coaching, rather focus on self } \\
\text { benefit, Not valuing "me" (my contribution, no recognition etc) }\end{array}$ & 12.34 & 5 \\
\hline Lack expertise, no experience and insight into problem solving & 12.32 & 6 \\
\hline No vision and direction (cannot share it) & 5.11 & 7 \\
\hline External reasons & 0.7 & 8 \\
\hline
\end{tabular}

\section{Findings}

Seven categories of actions that contribute to supervisory leadership failure were identified as shown in Exhibit 1. Below, we explore the main issues that were responsible for 94 percent of the behaviours mentioned by the respondents, and directly link them to the associated consequences they identified.

1. Posture. Topping the list of leadership failure causes was the leader's posture; that is, how the respondents judge the way their leaders treat team members and followers. Not surprisingly, leaders who act inflexibly and autocratically and reject other opinions are not well regarded by their followers. Respondents often referred to "ego" elements of the manager's language and behavior. Self-centered managers who routinely blame followers for problematic consequences were seen to be undermining their own legitimacy. [2] Arrogance was frequently mentioned as a leadership flaw. Another complaint was the leader who needs to "pull rank" to force subordinates to follow directives. 
2. No people skills. Eighteen percent of the respondents stated that their managers have "no people skills" and display little insight about values and relationships. By this, they meant their boss shows little integrity and trust. While this judgement might be subjective and derived from "evaluation bias," it includes being insensitive and not knowing how teams function. The apparent unwillingness to learn from mistakes and other people ended of this strong contributor.

3. Focus and thinking. Several respondents stated that their managers have no focus and display poor thinking. By this, they meant their boss was not thinking strategically. This judgement was mentioned by almost 14 percent of respondents and includes being non-strategic (suggesting more short-term thinking) and being taskinstead of person-focused. Negative thinking (fault-finding as focus) contributes to this judgement and could just as well be part of a negative-posture judgement.

4. Communication failure. Lack of communication involves a number of bad practicesfailing to share information, not listening to input, not giving feedback, and failing to delegate successfully. It's an overarching problem because even when managers are otherwise seen as competent, their inability to communicate gives rise to a perception of leadership failure.

5. Not giving encouragement, support and coaching. Lack of soliciting and accepting feedback is the underlying shortcoming in this category. If the manager focuses solely on the task with no or little concern for the follower, the imbalance makes the follower feel "valueless." Worse, though, is routinely assigning all blame to followers, as that destroys trust. Followers require leaders to value their contributions and recognize their potential.

6. Lacking expertise, insight, and skills. A number of respondents complained that their managers lacked expertise, insight, and certain skills, for example, problemsolving ability. In practice, this flaw may be a matter of perception, because the managers may have the expertise but are unable to use it convincingly. Lacking insight - the ability to judge situations correctly or identify the key issues - was mentioned by respondents as a failure of focus and thinking, but was often also linked to inadequate expertise.

7. No vision and direction. "Lesser" flaws that contribute to leadership failure include no vision, the inability to share vision and give direction and external factors.

\section{What then, are the consequences of managers' failure to lead?}

While we believe the reasons provided for their manager's leadership failure by followers are all subjective judgements of their manager's actions and behaviors, some degree of self-serving bias colored the respondents' judgements (confirmed by the fact that 0.7 percent of respondents referred to external factors as contributing to failure of their leaders).

Exhibit 2 shows the failure-consequences framework developed from the responses. Followers report many different feelings that led to all kinds of actions (or inactions) as well as direct and indirect consequences to the individual (I), team (T), organisation $(\mathrm{O})$, and leader $(\mathrm{L})$. The model classifies these feelings, actions, and consequences to meaningfully interpret the results. 
Exhibit 2. Consequences framework for leadership failure

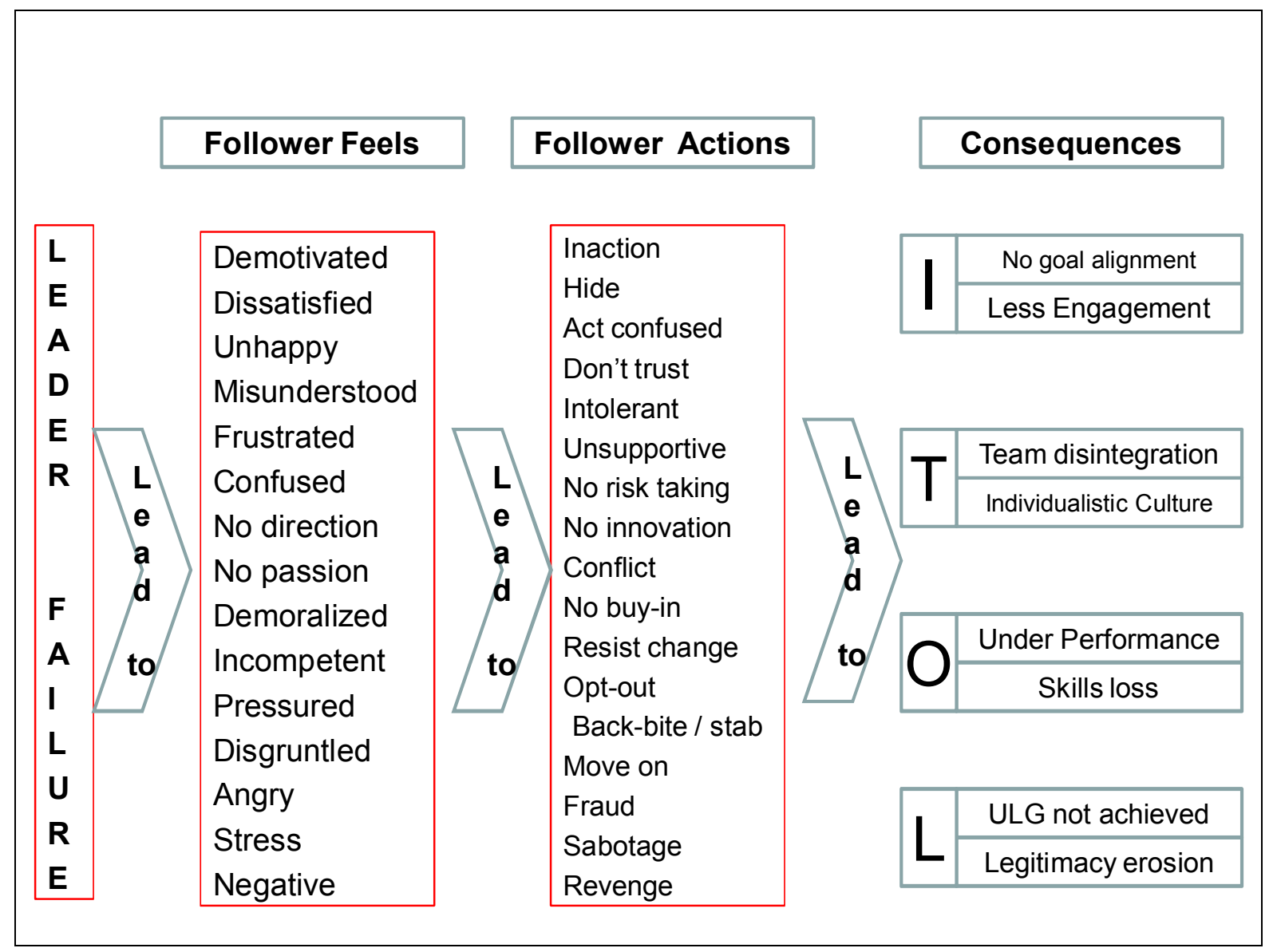

\section{Discussion of the findings and framework}

No formal definitions of failure and leadership were given to respondents before they answered the questions. They, however, showed an instinctive feel for what leadership is about as their responses largely concerned feeling and reactions - that is, human interactions. They made little mention of management issues and goals not achieved. Asking them to think about their own managers led to many personalized responses. Obviously the specific questions about failure provoked more focus on the negative aspects.[3] The question that then arises is, would we obtain a mirror image of our results if we had asked for actions contributing to their manager's success as a leader?

Feelings reported by respondents varied in degree of gravity (see Exhibit 2). Feelings of anger and negativity are more serious than just feeling dissatisfied. Obviously the more intense the feelings the more aggressive are the reactions and responses of the followers. Problematic situations that fester over time can also intensify the actions and eventual outcomes of the consequences. We were somewhat taken aback by some of the action responses that respondent verbalized--such as, back-stabbing, sabotage, and revenge. These actions are associated with grave consequences at all levels. Reporting these actions seems to suggest that the respondents were probably giving honest answers. Acknowledging these actions, and the anger and frustration associated with them, indicates that middle managers believe that their organizations have a serious problem with failed leadership. 
The consequences revealed in Exhibit 2 suggest severe penalties to failed leadership that any organization should try to avoid.

- Individuals (I) do not appear to align their personal goals with organizational goals, a situation that would lead to widespread non-engagement.

- Team (T) participation decreases, which supports development of a "me-first" culture.

- The organisation (O) suffers lower performance and skills loss when people leave for better opportunities in other firms or just do not wholeheartedly participate using all their skills.

- Finally, from the leader's perspective (L), when individuals stop volunteering or taking initiative, the leader's effectiveness is eroded. This makes it more difficult to share the vision, give feedback, obtain correct information, and access networks. Together, when trust is lost, these consequences make the leader unable to achieve the ultimate leadership goal (ULG) of developing more leaders.

\section{Lessons learned}

The main insight for managers who want to develop their leadership potential is that they are likely to be judged by what they do not do, rather than what they do. Exhibit 1 contains many examples like not recognising, not sharing information and more in support. What then can be done to make them better leaders? We offer three key practical suggestions:

- Accept that leadership mistakes will be made, but in order to learn from them, identify the causes. Awareness of the relationships shown in the model can trigger remedial action for the manager that recognizes these problems. Remember that the judgements depend on perception and therefore develop relationships with followers to understand their views. Cultivate empathy.

- Deliberate training in the basic tools of being a good manager of people is required. Tools should include basics such as proper delegation, giving clear instruction, time management, and regularly planned feedback mechanisms. At a more advanced level, organizations can offer training in the techniques of delegation understanding thinking preferences, coaching, and mentoring.

- Finally, measurement and inclusion of subordinate assessments in management scorecards is a must. If you don't measure "it" (leader performance), you can't give feedback, and people don't do it.

Often people ask: Can we afford to pay so much attention to such feedback based on colleagues' perceptions? After looking at the consequences, the question should be: Can you afford not to?

\section{Acknowledgements}

The contribution of the respondents from the banking and financial services industry that participated in the research and workshops is acknowledged with gratitude.

\section{References}

1 Mclean, B. \& Elkind, P. 2004. The Smartest Guys in the Room - The Amazing Rise and Scandalous Fall of Enron. Penguin Books.

2 Pretorius, M. 2009. "Leadership liabilities of newly appointed managers - arrive prepared." Strategy \& Leadership. Vol. 37 (4) 37-42.

3 Porter, M. E., Lorch, J.W. \& Nohria, N. 2004. "Seven surprises for new CEOs." Harvard Business Review. December, 62 - 72. 


\begin{tabular}{|l|l|}
\hline Purpose of this paper & $\begin{array}{l}\text { The paper endeavoured to determine the reasons why } \\
\text { managers fail at leadership }\end{array}$ \\
\hline $\begin{array}{l}\text { Design/methodology/ } \\
\text { approach }\end{array}$ & $\begin{array}{l}\text { Junior and middle managers were asked to judge why } \\
\text { managers generally fail as leaders and what they think the } \\
\text { consequences are when there is leadership failure. They } \\
\text { were prompted to consider their own managers first. } \\
\text { Their responses were categorised, ranked and reported. } \\
\text { Thereafter a framework was developed to explain the } \\
\text { consequences to better understand the impact of } \\
\text { leadership failure. }\end{array}$ \\
\hline Findings & $\begin{array}{l}\text { Managers fail at leadership as a result of poor posture, } \\
\text { lack of "people skills", unfocused thinking, failed } \\
\text { communication, not giving encouragement and support, } \\
\text { lack of expertise, lack of experience and insight as well as } \\
\text { lack of vision and direction. The consequences influence } \\
\text { the individual, team, organisation and leadership within } \\
\text { the organisation through the feelings that it create and the } \\
\text { subsequent actions that followers take. }\end{array}$ \\
\hline $\begin{array}{l}\text { Research } \\
\text { limitations/implicatio } \\
\text { ns (if applicable) }\end{array}$ & $\begin{array}{l}\text { The findings indicate mainly subjective evaluations and it } \\
\text { was not possible to distinguish between general } \\
\text { perceptions and potential personal issues and "gripes" of } \\
\text { the respondents. }\end{array}$ \\
\hline $\begin{array}{l}\text { Practical } \\
\text { implications } \\
\text { (if applicable) }\end{array}$ & $\begin{array}{l}\text { Leadership failure is a fact but to learn from it is crucial. } \\
\text { This can be done through training but also require that } \\
\text { leadership should be measured to give feedback and } \\
\text { sensitise leaders about its effects. }\end{array}$ \\
\hline $\begin{array}{l}\text { What is } \\
\text { original/value of } \\
\text { paper }\end{array}$ & $\begin{array}{l}\text { The reported consequences of leadership failure contain } \\
\text { acknowledged and addressed. }\end{array}$ \\
\hline
\end{tabular}

